\title{
SERANGAN BOKTOR (Xystrocera festiva Pascoe) DAN KARAT TUMOR (Uromycladium tepperianum (Sacc.) McAlpine) PADA SENGON (Falcataria mollucana (Miq.) DI PERKEBUNAN TEH CIATER
}

\author{
Wida Darwiati* dan Illa Anggraeni \\ Pusat Penelitian dan Pengembangan Hutan \\ Kampus Balitbang Kehutanan, Jln. Gunung Batu No. 5 Kotak Pos 165 Bogor 16118 \\ Telp 0251-8633234, 7520067 \\ e-mail:wdarwiati@yahoo.com
}

\author{
ABSTRACT \\ The Boktor And Tumor Attack At Sengon In The Plantation Of Tea Ciater
}

\begin{abstract}
Sengon has become one of the preferred tree because it has many advantages over other commercial tree species. It was widely cultivated with a monoculture system, like agricultural cultivation. The consequence of monoculture planting system was the unstable microclimate environment, so the ecosystem was susceptible to the pest and disease explosion. As happens at the Ciater plantation site, sengon plants were attacked by pests and diseases. The purpose of research were to study the extent data and intensity of boktor pests and tumor rust disease, boktor pest and bioecological behavior causing tumor rust on sengon as a protective and shade plant. The percentage and intensity of attacks caused by boktor pests and tumor rust disease was relatively high.The lowest percentage of boktor attacks was $40 \%$ and the highest was $90 \%$. It could be categorized as serious severity, even dead plants. The percentage and intensity of the attacks indicated that the pests living on sengon could thrive in suitable food sources. Likewise with the percentage and intensity of attacks caused by rust disease has reached $100 \%$, so it could be categorized as the level of damage was high.
\end{abstract}

Keywords: boktor pests, intensity of attack, percentage, sengon, tumor rust disease .

\begin{abstract}
ABSTRAK
Sengon salah satu pohon yang memiliki banyak keunggulan dibandingkan jenis pohon lainnya, dan banyak dibudidayakan secara luas dengan sistem monokultur seperti budidaya pertanian. Konsekuensi sistem tanam monokultur adalah lingkungan mikroklimat yang tidak stabil, sehingga ekosistemnya rentan terhadap hama dan penyakit. Tujuan dari penelitian ini, untuk memperoleh data luas dan intensitas serangan hama boktor dan penyakit karat tumor, perilaku hama boktor dan bioekologi penyebab penyakit karat tumor pada sengon. Metode yang digunakan adalah pengamatan visual setiap tegakan yang terserang oleh hama boktor dan penyakit karat tumor. Persentase dan intensitas serangan akibat hama dan penyakit ini relatif tinggi, untuk hama boktor persentase dan intensitas terendah adalah $40 \%$, sedangkan yang tertinggi $90 \%$, sehingga dapat dikategorikan tingkat keparahan berat, bahkan ada tanaman yang mati. Persentase dan intensitas serangan tersebut menunjukkan bahwa hama yang hidup pada tegakan sengon, berkembang dengan sumber makanan yang cocok. Begitu juga dengan persentase dan intensitas serangan akibat penyakit karat tumor sudah mencapai $100 \%$, sehingga dapat dikategorikan tingkat keparahan yang tergolong berat.
\end{abstract}

Kata Kunci : boktor, intensitas serangan, karat tumor, persentase serangan, sengon.

\section{PENDAHULUAN}

Sengon (Paraserianthes falcataria) merupakan salah satu pionir pohon multipurpose tree species di Indonesia. Pohon ini menjadi bahanbakuyang sangat baik untuk industri karena kecepatan tumbuh yang baik, dapat hidup di berbagai kondisi tanah, serta bahan baku yang baik untuk industri panel kayu dan kayu lapis. Kebutuhan kayu Sengon ini cukup besar karena kayu sengon sering dipakai untuk bahan baku meubel berkualitas menengah ke bawah, penyangga cor bangunan, pembuatan rumah, bahan baku kertas, dan lain-lain. Dengan harga yang cukup menggiurkan saat ini sengon banyak diusahakan untuk berbagai keperluan dalam bentuk kayu olahan berupa papan dengan ukuran tertentu sebagai bahan baku pembuat peti, papan penyekat, pengecoran semen dalam konstruksi, industri korek api, pensil, papan partikel dan bahan baku industri pulp kertas. 
Pohon sengon umur 1 tahun dapat mencapai tinggi $7 \mathrm{~m}$, dan umur 12 tahun dapat mencapai tinggi $39 \mathrm{~m}$ dengan diameter lebih dari $60 \mathrm{~cm}$ dan tinggi cabang 10-30 m. Diameter pohon yang sudah tua dapat mencapai $1 \mathrm{~m}$, bahkan kadang lebih. Batang umumnya tidak berbanir, tumbuh lurus, dan silindris. Pohon sengon memiliki kulit licin, berwarna abu-abu, atau kehijau-hijauan (Siregar, et al., 2009).

Pohon sengon umumnya berukuran cukup besar dengan tinggi pohon total mencapai $40 \mathrm{~m}$ dan tinggi bebas cabang mencapai $20 \mathrm{~m}$. Diameter pohon dewasa dapat mencapai $100 \mathrm{~cm}$ atau kadang-kadang lebih, dengan tajuk lebar mendatar. Apabila tumbuh ditempat terbuka sengon cenderung memiliki kanopi yang terbentuk seperti kubah atau payung. Pohon sengon pada umumnya tidak berbanir meskipun dilapangan kadang dijumpai pohon dengan banir kecil. Permukaan kulit batang berwarna putih, abu-abu atau kehijauan, halus, kadang-kadang sedikit beralur dengan garis-garis lentisel memanjang (Krisnawatiet al., 2011).Tanaman Sengon dapat tumbuh baik pada tanah regosol, aluvial, dan latosol yang bertekstur lempung berpasir atau lempung berdebu, dengan kemasaman tanah sekitar $\mathrm{pH}$ 6-7. Ketinggian tempat yang optimal untuk tanaman sengon antara 0 $800 \mathrm{~m}$ dpl. Walapun demikian, tanaman sengon ini masih dapat tumbuh sampai ketinggian $1500 \mathrm{~m}$ di atas permukaan laut. Sengon termasuk jenis tanaman tropis, sehingga untuk tumbuhnya memerlukan suhu sekitar $18^{\circ}-27^{\circ} \mathrm{C}$. Tanaman sengon membutuhkan batas curah hujan minimum yang sesuai, yaitu 15 hari hujan dalam 4 bulan terkering, namun juga tidak terlalu basah, dan memiliki curah hujan tahunan yang berkisar antara 2000 - $4000 \mathrm{~mm}$. Tanaman sengon membutuhkan kelembaban sekitar 50\%-75\% (Nasution, 2008).

Budidaya tanaman sengon akan dipengaruhi oleh beberapa faktor pembatas (penghambat) pertumbuhan. Salah satu faktor pembatas utama adalah serangan hama dan penyakit tanaman. Hama tanaman sengon merupakan organisme pengganggu tanaman dari binatang serangga, mamalia, nematoda (cacing) dan lain-lain, sementara penyakit sengon merupakan organisme pengganggu tanaman dari kelompok mikroba seperti jamur, bakteri, virus dan lain-lain. Secara umum hambatan yang disebabkan oleh serangan Hama Penyakit Tanaman (HPT) dapat menurunkan hasil rata-rata $12 \%$ - $15 \%$. Pada tanaman dan kondisi tertentu, hambatan HPT dapat menurunkan produksi hingga $100 \%$. Tanaman tertentu memiliki jenis hama dan penyakit tertentu dengan tingkat serangan yang berbeda-beda dari waktu ke waktu. Tantangan terberat budidaya sengon adalah tingkat serangan hama dan penyakit yang dapat menurunkan produksi sangat nyata, namun tantangan tersebut dapat dikendalikan dengan mudah asalkan para pengelola hutan memahami, melaksanakan dan tertib dalam melakukan budidaya tanaman yang sehat dan melakukan pengendalian dengan benar.

Tujuan dari penelitian ini, untuk memperoleh data luas dan intensitas serangan hama boktor dan penyakit karat tumor, perilaku hama boktor, dan bioekologi penyebab penyakit karat tumor pada tanaman sengon, sebagai tanaman pelindung dan peneduh di areal Perkebunan Teh PT. Perkebunan Nusantara VIII, Kebun Ciater, Jawa Barat.

\section{BAHAN DAN METODE}

\section{Bahan dan Alat}

Tanaman sengon umur 3 tahun sebagai tanaman peneduh di areal perkebunan teh, alkohol $70 \%$, spirtus, aluminium foil, kertas koran, kertas tisu dan tali rafia. Alat yang digunakan gelas obyek, kaca penutup, alat pemotong (golok, gunting dan scalpel), pinset, jarum ose, lampu bunsen, jaring serangga, kotak serangga, cawan petri, kapas, counter, ice box,kamera, mikroskop dan lain-lain.

\section{Metode Penelitian \\ Kegiatan di lapangan}

Pengamatan dilakukan secara visual terhadap setiap tegakan yang terserang hama dan penyakit, jumlah pohon yang diamati sebanyak 120 dengan tinggi rerata $16-20$ meter. Kemudian dilakukan pengambilan material hama dan penyakit untuk penelitian 
di Laboratorium. Selanjutnya menghitung persentase (proporsi tanaman yang terserang hama dan penyakit dalam suatu populasi tanpa memperhitungkan berat atau ringannya tingkat serangan) dan intensitas serangan, dengan rumus :

$$
K P=\frac{n}{N} \times 100 \%
$$

$$
\begin{array}{ll}
\mathrm{KP} & =\text { persentase kejadian penyakit } \\
\mathrm{n} & =\text { jumlah pohon yang terserang } \\
& \text { hama dan penyakit dalam plot } \\
& \text { pengamatan } \\
\mathrm{N} & =\text { jumlah seluruh pohon yang } \\
& \text { diamati }
\end{array}
$$

Intensitas serangan suatu patogen dihitung dengan rumus :

$$
I P=\frac{\sum(n x v)}{N x Z} \times 100 \%
$$

I P = Intensitas penyakit

$\mathrm{N}=$ Jumlah pohon yang diamati

$\mathrm{n}=$ Pohon yang terserang karat tumor

$\mathrm{v}=$ Nilai kategori serangan

$\mathrm{Z}=$ Nilai kategori serangan tertinggi

\section{Kegiatan di Laboratorium}

Pemeliharaan (rearing) hama dan pengamatan mikroskopis penyakit. Pengamatan spora fungi patogen penyakit (Uromycladium tepperianum) dilakukan dengan pembuatan preparat basah secara sederhana. Pembuatan preparat basah diambil bagian jaringan yang muda dengan mengiris setipis mungkin (transparan), irisan diletakkan pada gelas obyek yang sudah diberi setetes air. Kemudian gelas obyek ditutup, sehingga tidak terjadi gelembung udara, preparat diamati di bawah mikroskop. Selain pembuatan preparat basah dibuat pula preparat permanen untuk mengetahui bentuk tubuh buah fungi patogen karat tumor.

Pemeliharaan (rearing) hama boktor dilakukan dengan cara larva yang diperoleh dari lapangan dengan berbagai instar, dimasukkan kedalam kotak serangga, kemudian diberi potongan batang sengon untuk pakannya dan diamati setiap hari.

\section{HASIL DAN PEMBAHASAN}

\section{Pengamatan Visual Gejala Serangan Hama Boktor}

Gejala serangan hama boktor adanya retakan pada kulit pohon (pecahpecah), dari retakan tersebut, keluar cairan berwarna coklat sampai coklat kehitamhitaman, juga keluar serbuk kayu yang agak halus dan masih segar dengan warna keputih-putihan menempel pada kulit pohon. Serbuk ini merupakan hasil aktivitas larva sejak menetas dari telur yang memakan jaringan kulit dengan cara menggerek disekitar lokasi larva berada. Adanya serbuk gerek yang menempel pada permukaan kulit batang pohon bagian luar tersebut, dapat menjadi petunjuk terjadinya gejala serangan awal tanaman terserang hama boktor (Gambar 1).

Xystrocera festiva Thombs. (Coleoptera : Cerambycidea) atau sering disebut sebagai boktor atau uter-uter, sampai saat ini dianggap sebagai hama yang paling merugikan pada hutan sengon karena menyebabkan kematian, patahnya batang dan menurunkan jumlah dan kualitas kayu yang dihasilkan (Husaeni, 2010).

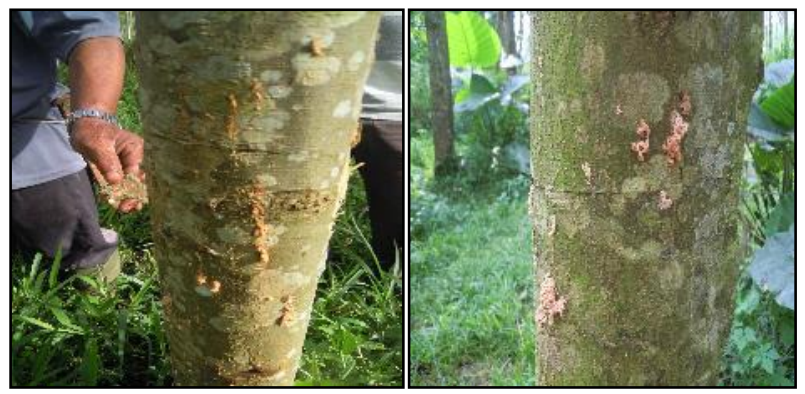

Gambar 1. Gejala Serangan Awal Hama Boktor 

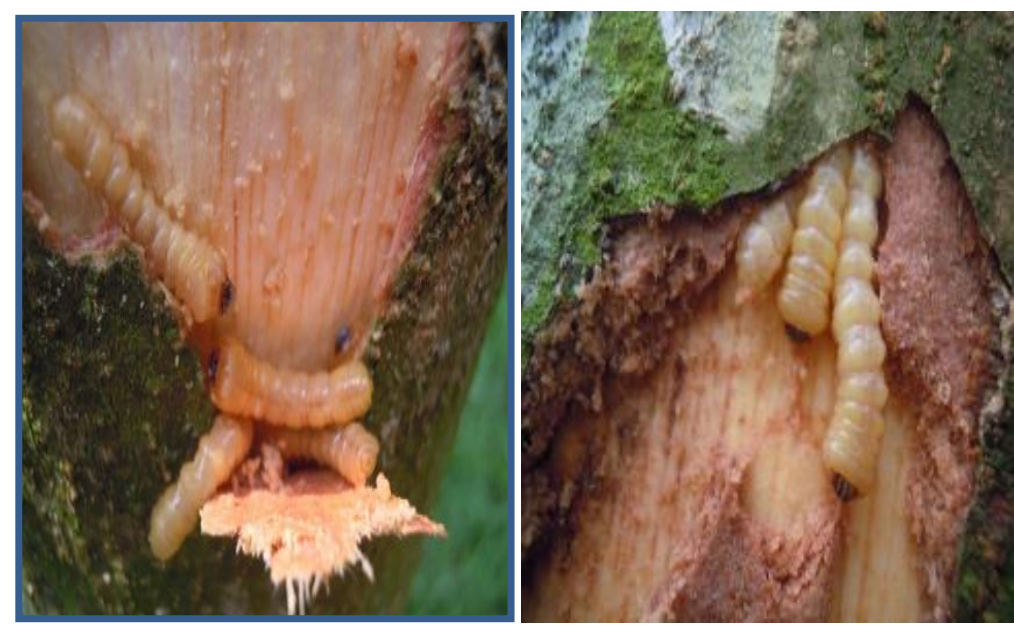

Gambar 2. Larva Boktor yang Berada antara Kulit Batang dengan Kayu Gubal

\section{Pengamatan Visual Gejala Serangan Penyakit Karat Tumor}

Pengamatan di lapangan menunjukkan gejala yang khas, yaitu pertumbuhan lebih pada bagian yang terserang. Gejala diawali dengan adanya pembengkakan lokal di bagian yang terserang (daun, cabang, dan batang), lama kelamaan pembengkakan berubah menjadi benjolan, kemudian menjadi bintil kecil atau disebut tumor (gall). Tumor yang timbul mempunyai bentuk bervariasi, mulai bulat sampai tidak beraturan dengan diameter dari beberapa milimeter sampai lebih besar dari $10 \mathrm{~cm}$. Tumor tersebut dapat berkelompok atau menyebar pada bagian yang terserang. Tumor yang masih muda berwarna hijau kecoklat-coklatan, diselimuti oleh lapisan seperti tepung berwarna kemerah-merahan, merupakan kumpulan dari spora patogen.
Sedangkan, tumor yang tua berwarna coklat kemerah-merahan sampai hitam, dan biasanya tumor sudah keropos berlubang, serta digunakan sebagai sarang semut atau serangga lainnya. Apabila yang terserang penyakit bagian tangkai daun majemuk atau tajuk, maka bagian tersebut agak membengkok karena adanya penebalan dan pembengkakan, kemudian tajuk daun menggulung berubah bentuk (malformasi) tanpa daun lagi. Serangan pada daun diawali dengan bentuk daun agak mengeriting, tangkai daun terbentuk tumor (Gambar 3). Jika tanaman mengalami serangan yang parah, maka seluruh bagian tanaman dipenuhi oleh tumor, kemudian daun mengering, mengalami kerontokan, diikuti oleh batang dan cabang pohon (Gambar 4) dan akhirnya tanaman mati.
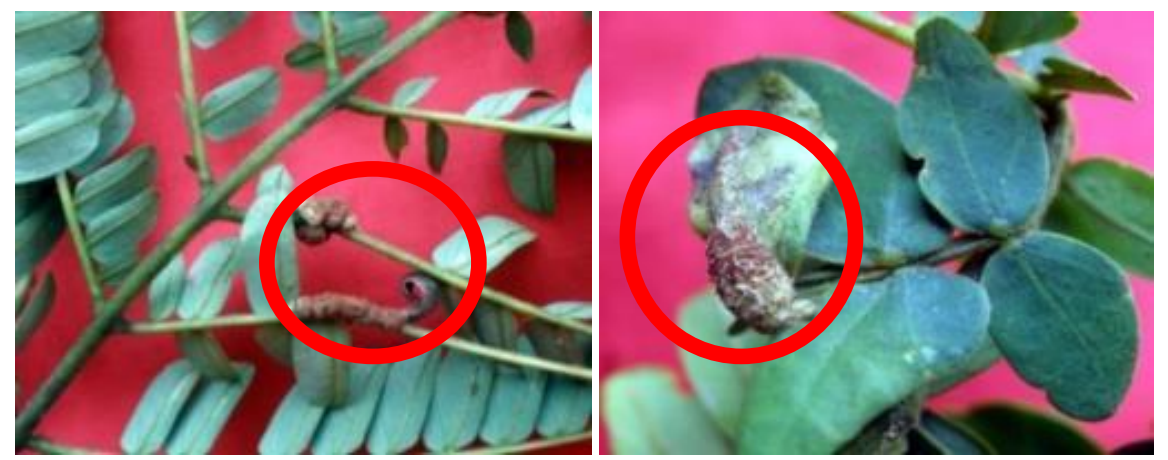

Gambar 3. Gejala Awal Penyakit Karat Tumor pada Daun Majemuk dan Tangkai Daun 

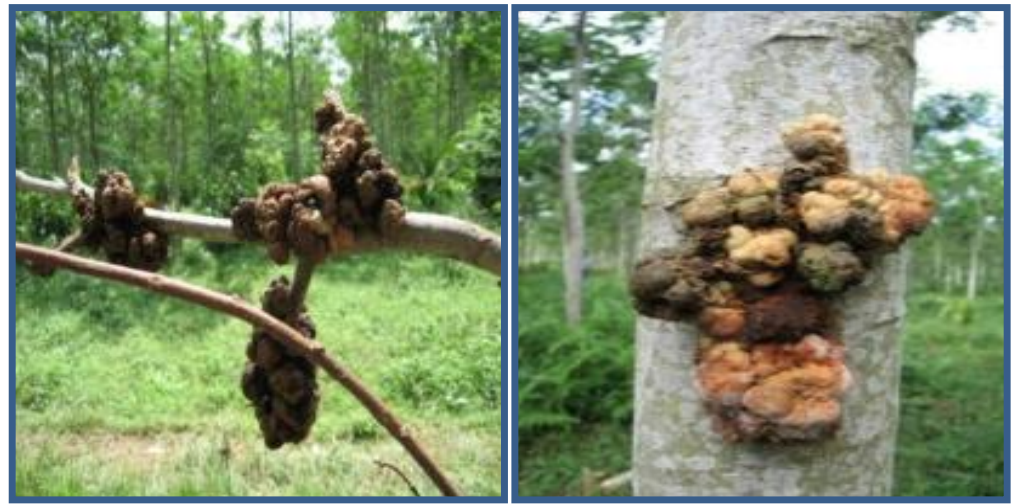

Gambar 4. Karat Tumor Pada Batang dan Cabang Pohon Sengon

Hasil pengamatan mikroskopis pada preparat basah dan preparat permanen di laboratorium, terlihat piknium dalam keadaan tertutup maupun terbuka ke atas permukaan lapisan epidermis, piknidium berbentuk bulat/mangkok atau berbentuk seperti botol. Piknium berwarna coklat kemerah-merahan (Gambar 5). Fungi menghasilkan teliospora berbentuk bulat seperti payung (bagian pinggirnya bergerigi), atau oleh Old (2002) dalam Anggraeni dan Lelana (2011) dikatakan bahwa teliospora fungi mempunyai rabungrabung yang radial, setiap satu tangkai terdiri dari tiga Teliospora (Gambar 5). Ukuran spora berkisar lebar $14-20 \mu \mathrm{m}$ dan panjang $17-28 \mu \mathrm{m}$ (Rahayu dan Lee dalam Rahayu, 2008). Infeksi dapat terjadi pada biji, semai maupun tanaman dewasa di lapangan dan semua bagian tanaman seperti pucuk, daun, cabang, ranting, batang dan bunga dapat terinfeksi oleh fungi tersebut (Rahayu et al., 2005 dalam Rahayu, 2008).
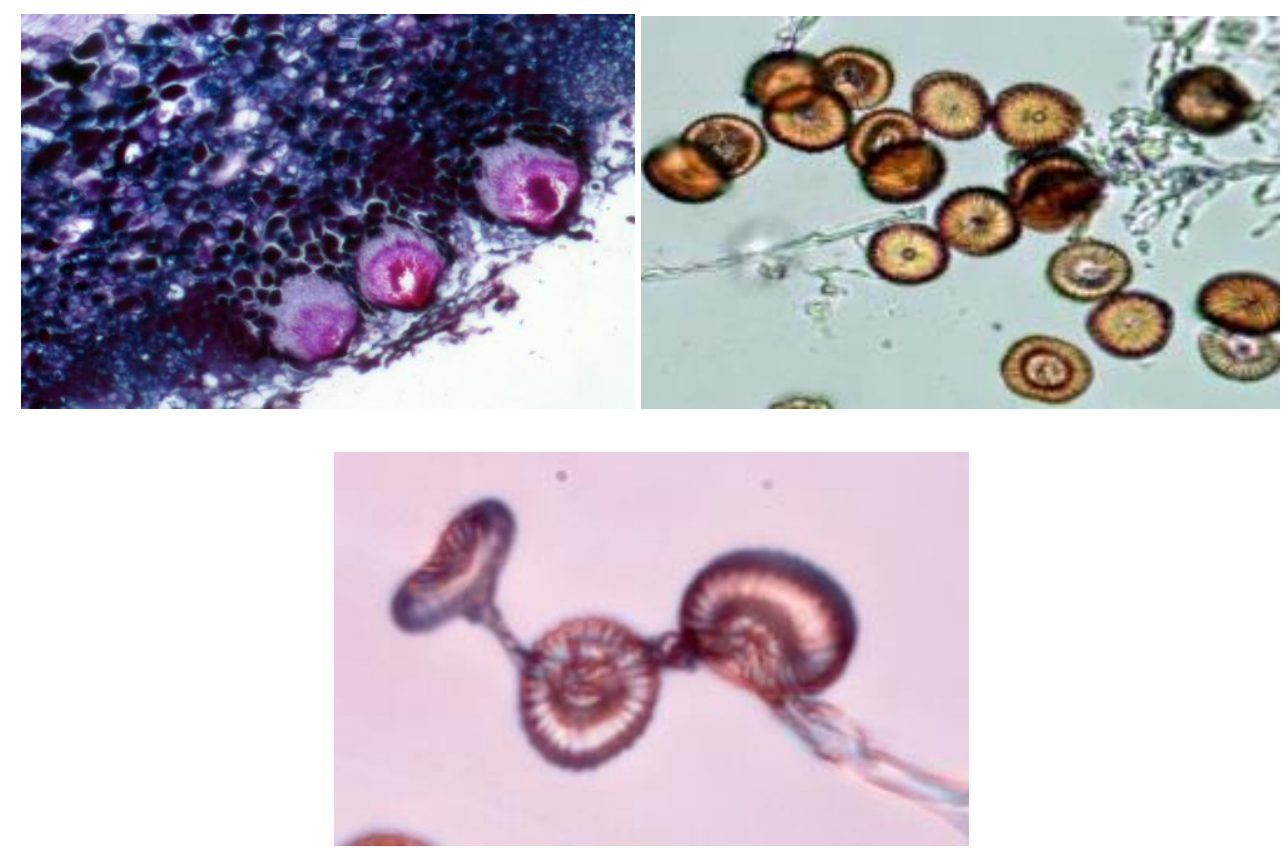

Gambar 5. Piknium dan Teliospora Fungi Patogen Karat Tumor 
Persentase dan Intensitas Serangan Hama Boktor dan Penyakit Karat Tumor

Hasil perhitungan persentase dan intensitas serangan hama boktor dan penyakit karat tumor, dapat dilihat pada Tabel 1 dan 2. Dari hasil Tabel 1 dan 2 persentase dan intensitas serangan hama boktor rata-rata 56,66\%, persentase dan intensitas penyakit karat puru sebesar 100\% (kategori rusak), sedangkan persentase dan intensitas serangan hama boktor dan penyakit karat puru sebesar 56,66 $\%$.

Tabel 1. Persentase Serangan dan Intensitas Serangan Hama Boktor dan Penyakit Karat Tumor (Percentage of Attack and Intensity of Boktor Pest Attack and Rust Disease of Tumor).

\begin{tabular}{|c|c|c|c|c|c|c|c|}
\hline No & $\begin{array}{c}\text { Jumlah } \\
\text { Pohon } \\
\text { yang } \\
\text { Diamati } \\
\text { (Number } \\
\text { off Trees } \\
\text { Observed } \\
\text { ) } \\
\end{array}$ & $\begin{array}{c}\text { Jumlah } \\
\text { Pohon } \\
\text { Terserang } \\
\text { Hama } \\
\text { Boktor(Num } \\
\text { ber of trees } \\
\text { infected by } \\
\text { boktor) } \\
\end{array}$ & $\begin{array}{c}\text { Persentase/ } \\
\text { Intensitas } \\
(\%)\end{array}$ & $\begin{array}{c}\text { Status } \\
\text { Serangan } \\
\text { (Actack } \\
\text { status) }\end{array}$ & $\begin{array}{c}\text { Jumlah Pohon } \\
\text { Terserang } \\
\text { Penyakit Karat } \\
\text { Tumor } \\
\text { ( Number of } \\
\text { tress infected } \\
\text { by rust } \\
\text { disease) }\end{array}$ & $\begin{array}{l}\text { Persentase/ } \\
\text { Intensitas } \\
(\%)\end{array}$ & $\begin{array}{c}\text { Status } \\
\text { Serangan } \\
\text { (Actack } \\
\text { status) }\end{array}$ \\
\hline 1. & 10 & 6 & 60 & berat & 10 & 100 & Berat \\
\hline 2. & 10 & 7 & 70 & berat & 10 & 100 & Berat \\
\hline 3. & 10 & 5 & 50 & berat & 10 & 100 & Berat \\
\hline 4. & 10 & 9 & 90 & berat & 10 & 100 & Berat \\
\hline 5. & 10 & 6 & 60 & berat & 10 & 100 & Berat \\
\hline 6. & 10 & 7 & 70 & berat & 10 & 100 & Berat \\
\hline 7. & 10 & 4 & 40 & berat & 10 & 100 & Berat \\
\hline 8. & 10 & 4 & 40 & berat & 10 & 100 & Berat \\
\hline 9. & 10 & 5 & 50 & berat & 10 & 100 & Berat \\
\hline 10. & 10 & 5 & 50 & berat & 10 & 100 & Berat \\
\hline 11. & 10 & 6 & 60 & berat & 10 & 100 & Berat \\
\hline \multirow[t]{3}{*}{12.} & 10 & 4 & 40 & berat & 10 & 100 & Berat \\
\hline & & & 6.800 & & & 1.200 & \\
\hline & \multicolumn{2}{|c|}{ Rata-rata } & 56,66 & & & 100 & \\
\hline
\end{tabular}

Tabel 2. Jumlah Tanaman yang Terserang Hama Boktor dan Penyakit Karat Tumor secara Bersamaan.(Number off Trees infected by pest and disease)

\begin{tabular}{|c|c|c|c|c|}
\hline No. & $\begin{array}{c}\text { Jumlah Pohon } \\
\text { yang } \\
\text { Diamati(Number } \\
\text { off Trees } \\
\text { Observed) }\end{array}$ & $\begin{array}{c}\text { Jumlah Pohon Terserang } \\
\text { Hama Boktor Sekaligus } \\
\text { Terserang Penyakit Karat } \\
\text { Tumor. } \\
\text { (Number of trees infected } \\
\text { by boktor pest and rust } \\
\text { disease) } \\
\end{array}$ & $\begin{array}{c}\text { Persentase/ } \\
\text { Intensitas } \\
(\%)\end{array}$ & $\begin{array}{l}\text { Status Serangan } \\
\text { (Actack status) }\end{array}$ \\
\hline 1. & 10 & 6 & 60 & Berat \\
\hline 2. & 10 & 7 & 70 & Berat \\
\hline 3. & 10 & 5 & 50 & Berat \\
\hline 4. & 10 & 9 & 90 & Berat \\
\hline 5. & 10 & 6 & 60 & Berat \\
\hline 6. & 10 & 7 & 70 & Berat \\
\hline 7. & 10 & 4 & 40 & Berat \\
\hline 8. & 10 & 4 & 40 & Berat \\
\hline 9. & 10 & 5 & 50 & Berat \\
\hline 10. & 10 & 5 & 50 & Berat \\
\hline 11. & 10 & 6 & 60 & Berat \\
\hline \multirow[t]{3}{*}{12.} & 10 & 4 & 40 & Berat \\
\hline & & $\Sigma$ & 6.800 & \\
\hline & & Rata-rata & 56,66 & \\
\hline
\end{tabular}




\section{PEMBAHASAN}

Gejala awal serangan hama boktor dicirikan dengan adanya retakan pada kulit batang dan serbuk gerek yang menempel, karena bercampur dengan cairan yang keluar dari retakan. Hal ini terjadi karena perilaku imago boktor betina yang meletakkan telurnya secara berkelompok pada celahcelah, retakkan atau luka pada permukaan batang dan ranting pohon. Seekor kumbang betina dapat meletakkan kurang lebih 400 butir telur (Anonim., 2009; Duladi., 2012). Telur berwarna putih kekuning-kuningan dengan ukuran $\pm 1 \mathrm{~mm}$ berbentuk lonjong agak pipih, telur menetas, keluarlah larva (ulat) instar 1. Larva berbentuk gilik dengan warna kuning gading, bagian kepala berwarna coklat, pada permukaan tubuh tampak jelas adanya guratan-guratan searah dengan lingkaran tubuh. Pada stadia larva inilah tahap kehidupan yang selalu aktif memakan dan menggerek batang sengon, dan selama perkembangan larva dari instar 1 sampai dengan instar berikutnya selalu berada diantara kulit batang dan permukaan kayu gubal. Larva menggerek jaringan kulit batang pohon sengon bagian dalam atau permukaan kayu atas mengarah ke bawah batang (Gambar 6), stadium larva sangat panjang, diperlukan waktu 118 hari atau kurang lebih 4 bulan. Duladi (2012) mengatakan bahwa larva yang baru menetas akan segera memakan kulit bagian dalam dan bagian dari kayu gubal membentuk saluran-saluran $\pm 0,5 \mathrm{~cm}$ ke arah bawah batang, saluran gerek ini seluruhnya tertutup oleh ekskremen yang dihasilkan larva. Biasanya saluran gerek saling bersambungan, semakin ke bawah saluran gerek semakin melebar, karena ukuran larvanya juga makin membesar. Banyaknya serbuk gerek ini bervariasi tergantung pada umur dan banyaknya larva yang ada dalam kulit, bahkan serbuk gerek seringkali juga jatuh ke lantai hutan. Pada saat larva akan menjadi pupa, larva membentuk lubang gerek ke dalam kayu gubal kemudian membelok ke arah atas, bentuk lubang gerek oval berukuran $\pm 0,75-1,33 \mathrm{~cm}$, dalamnya mencapai 15 - $20 \mathrm{~cm}$. Pada ujung lubang gerek dibuat sedikit lebih lebar yang digunakan untuk ruang pupasi, setiap ruang pupasi hanya diisi satu larva boktor. Kumbang dewasa keluar, pada saat kumbang meninggalkan lubang gerek, umumnya tingkat kerusakan batang sudah parah, sebagian kulit batang terkelupas, luka gerek di permukaan tampak seperti ukiran dengan lubang-lubang yang kosong sebagai pertanda sudah ditinggalkan (Gambar 7). Kumbang boktor berwarna coklat kekuningkuningan agak mengkilap, di bagian pinggir dari elitra dan sekeliling pronotum terdapat garis lebar yang berwarna hijau kebiruan yang mengkilap. Ukuran tubuh kumbang jantan agak lebih kecil dari kumbang betina, panjang antena 1,5 kali panjang tubuhnya dan kakinya lebih panjang dan lebih kokoh (Anonim., 2016) (Gambar 8).

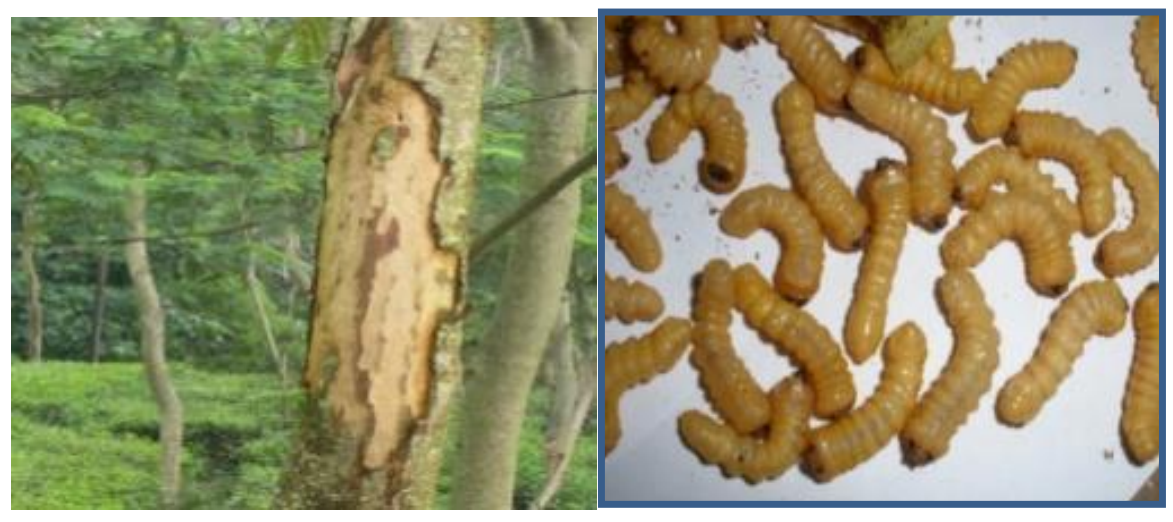

Gambar 6. Larva Boktor dan Kerusakan pada Batang Akibat Pola Makan dan Gerekan dari Larva. 


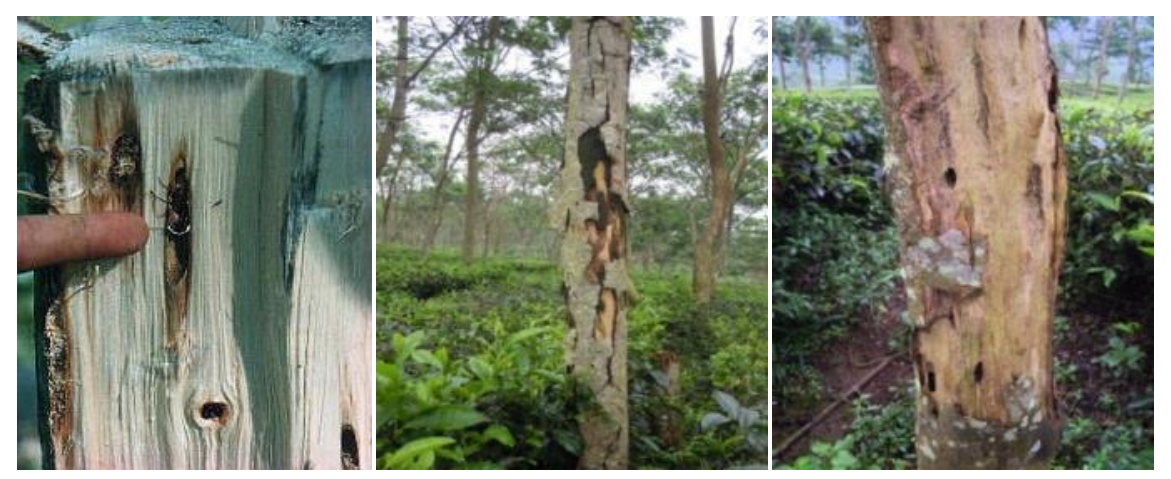

Gambar 7. Lubang Gerek yang Sudah Ditingalkan Imago dan Imago yang Masih Ada di dalam Lubang Gerek

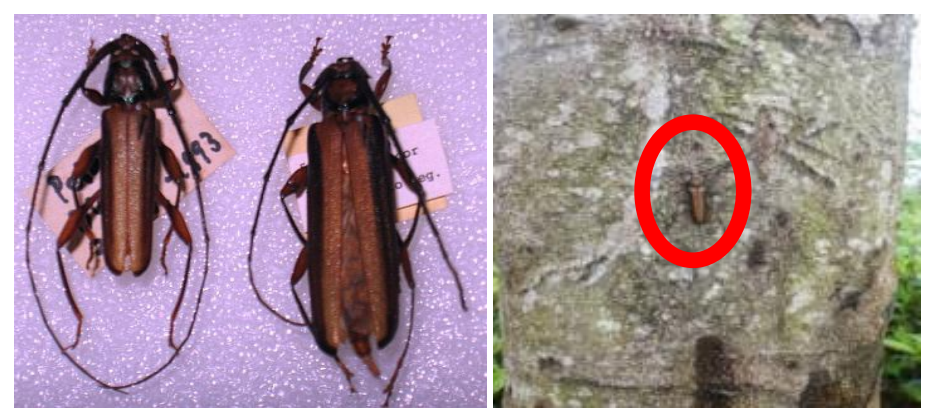

Gambar 8. Imago Boktor (Xystrocera festiva)

Kumbang boktor adalah serangga nokturnal yaitu serangga yang aktif pada malam hari, melakukan aktivitas terbang, perkawinan dan bertelur pada malam. Siklus hidup sempurna dengan tahapan yang dimulai dari telur - larva - pupa - imago. Secara alami perkembangan dari telur sampai imago memakan waktu 253 hari untuk kumbang jantan, dan 250 hari untuk kumbang betina. Umur rata-rata kumbang jantan 11,5 hari 15 hari, dan umur rata-rata kumbang betina 5,3 hari - 11 hari (Husaeni, 2001). Waktu perkawinan dan bertelur terjadi beberapa jam setelah kumbang keluar. Waktu bertelur hanya terjadi dalam satu hari, kebanyakan kumbang hanya bertelur sampai 2 kali dalam waktu 2-8 hari. Umur kumbang betina ratarata 2 - 5 hari, dan kumbang jantan rata-rata 7 hari. Berdasarkan hasil pemeliharaan di laboratorium, waktu yang diperlukan untuk kelangsungan hidup mulai dari telur, larva, pupa dan imago adalah 174 hari atau kurang lebih 6 bulan, dan terpanjang adalah masa larva 118 hari (Husaeni, 2001).

Tingkat keparahan hama boktor dan penyakit karat tumor dalam penelitian ini, menggunakan tolok ukur seberapa parah kerusakan suatu tegakan hutan dalam suatu tingkatan. Perlu dilakukannya penilaian tingkat keparahan hama boktor dan penyakit karat tumor pada tegakan sengon, untuk menanggulangi kerusakan yang terjadi dengan menerapkan pengendalian hama dan penyakit tersebut. Keparahan hama dan penyakit (disease severity) merupakan proporsi atau persentase luas tanaman yang terserang. Sedangkan intensitas hama dan penyakit adalah gambaran kuantitatif meliputi kepadatan atau density jumlah individu per area, atau jumlah individu per volume yang terserang penyakit.

Hasil penghitungan persentase serangan dan intensitas serangan akibat hama boktor dan penyakit karat tumor pada lokasi penelitian relatif tinggi, untuk hama 
boktor persentase dan intensitas terendah $40 \%$, dan yang tertinggi $90 \%$, sehingga dapat dikategorikan memiliki tingkat keparahan yang tergolong berat, bahkan ada beberapa tanaman sengon yang mati. Persentase dan intensitas serangan tersebut menunjukkan bahwa $X$. festiva yang hidup pada tegakan sengon di areal perkebunan teh Ciater berkembang cepat karena sumber makanannya cocok. Sementara itu, persentase dan intensitas serangan akibat penyakit karat tumor sudah mencapai $100 \%$, sehingga dapat dikategorikan memiliki tingkat keparahan penyakit yang tergolong berat. $U$. tepperianum merupakan salah satu patogen yang monosiklik atau patogen daur tunggal (Anggraeni dan Lelana, 2011). Anonim (2014a) mengatakan bahwa patogen yang monosiklik adalah fungi karat, karena fungi tersebut menghasilkan spora pada akhir musim, spora tersebut berfungsi sebagai inokulum primer pada tahun berikutnya, dan sebagai satu-satunya sumber inokulum pada awal tahun tersebut. Pada patogen monosiklik, inokulum primer merupakan satu-satunya inokulum yang tersedia selama musim tersebut, karena tidak ada inokulum sekunder dan tidak ada infeksi sekunder, sehingga jumlah inokulum yang dihasilkan pada akhir musim tersebut lebih besar dari yang terdapat pada awal musim. Jumlah inokulum pada penyakit monosiklik mungkin akan meningkat terus menerus dari tahun ke tahun.

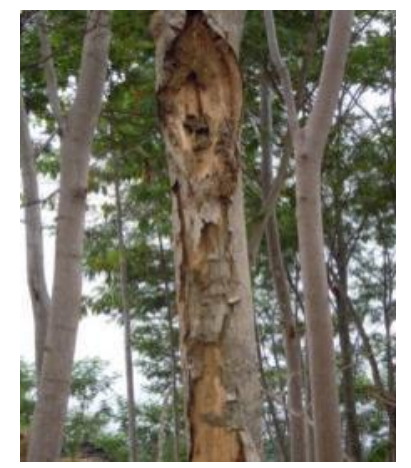

Gambar 9. Tegakan Sengon yang Terserang Boktor Juga Terserang karat Tumor

Fungi karat tumor bersifat parasit obligat seperti yang telah dijelaskan di atas, sehingga jenis fungi yang dapat tumbuh dan memperbanyak diri, apabila tetap berhubungan dengan tumbuhan inangnya yaitu sengon selama hidupnya. Selain itu, faktor lingkungan yang sangat berperan mempengaruhi awal perkembangan penyakit yang bersifat infeksi. Faktor lingkungan antara lain suhu, kelembaban, cahaya, keasaman dan lain-lain. Hal ini dapat digambarkan dengan segitiga penyakit. Untuk terjadi dan berkembangnya penyakit secara optimal, maka harus terdapat kombinasi tiga faktor yaitu tanaman inang yang rentan, patogen yang infektif, dan kondisi lingkungan yang menguntungkan. Berdasarkan pengamatan, penyakit dengan interval waktu tertentu atau hingga intensitas penyakit yang menimbulkan kerusakan berat, atau kematian tanaman seperti yang terjadi pada penelitian ini, dapat dikatakan bahwa penyakit karat tumor pada sengon di kebun teh Ciater dapat disebut dengan epidemi (epifitotik). Epidemi (epifitotik) yaitu patogen yang menyebar dan menyerang banyak individu dalam suatu populasi, meliputi areal yang luas dan dalam waktu yang relatif pendek (Meliala, 2009). Sebagian besar epidemi terjadi secara lokal dan menyebabkan kerugian dari tidak berarti sampai dengan sedang, namun epidemi tersebut masih dapat dikendalikan baik secara alami maupun dengan pengendalian buatan. Akan tetapi peristiwa serangan penyakit karat tumor pada sengon ini merupakan epidemi yang timbul secara tibatiba, perkembangannya sangat cepat, menyebar secara luas, serta menimbulkan serangan berat sehingga di luar kendali.

Keterkaitan faktor lingkungan dengan perkembangan suatu hama dan penyakit tanaman sangat jelas, mengingat tanaman tumbuh pada suatu media tumbuh, pada suatu ruang atau wilayah yang membutuhkan cahaya, kelembaban dan udara, serta berhubungan erat dengan keberadaan organisme lain. Rahayu (2007 dan 2008) menyatakan penyakit karat tumor berkembang intensif di daerah berkabut (kelembaban tinggi), adanya kabut di musim kemarau maupun musim penghujan, berpotensi meningkatkan terjadinya penyakit karat tumor baik di persemaian maupun di lapangan. Tanaman sengon yang tumbuh di 
tempat tinggi seperti di lereng bukit maupun gunung, berpeluang mendapatkan serangan karat tumor lebih besar dibanding tanaman sengon yang tumbuh di tempat rendah dan rata. Pada dasarnya, ketinggian tempat bukanlah faktor utama yang dapat meningkatkan resiko terjadinya serangan jamur karat ini. Namun kondisi lingkungan seperti kelembaban yang tinggi, angin yang perlahan serta adanya kabut, umumnya terdapat di lokasi yang relatif tinggi. Pendapat Rahayu tersebut di atas diperkuat lagi bahwa perkembangan suatu penyakit tanaman hutan secara umum mempunyai hubungan yang sangat erat dengan faktor lingkungan seperti lamanya periode sinar matahari, kecepatan angin, arah angin, kelembaban relatif, curah hujandan temperatur, keradaan kabut, intensitas naungan, serta kondisi dan jenis tanaman disekitarnya. Selanjutnya Rahayu juga mengatakan dari hasil penelitian dan monitoring selama 7 tahun di Pulau Jawa dan Sabah Malaysia, bahwa faktor lingkungan yang paling dominan berpengaruh terhadap perkembangan penyaki karat tumor adalah intensitas kabut, kelembaban relatif, dan kecepatan angin (Rahayu, 2014). Rahayu et al., 2010, penularan penyakit dapat terjadi melalui penyebaran teliospora dengan bantuan air (embun), angin, serangga dan manusia. Untuk perkecambahan teliospora diperlukan air, dan lamanya waktu berkecambah sangat tergantung pada suhu dan kondisi berkabut/gelap akan mempercepat perkecambahan teliospora. Fungi karat masih bisa tetap hidup di musim kemarau/kering pada bagian tanaman yang terserang. Pada waktu mulai musim hujan, serangan akan bertambah dan terus tersebar selama musim hujan. Menurut Nurhayati (2011), kelembaban mempengaruhi perkembangan penyakit, infeksi atau penetrasi, germinasi spora dan penyebaran spora. Sumber kelembaban ini berasal dari hujan, irigasi dan juga kelembaban relatif udara (RH). Kelembaban sangat berpengaruh terhadap perkembangan penyakit, karena patogen umumnya memerlukan adanya lapisan air atau kelembaban tertentu untuk dapat melakukan infeksi atau penetrasi pada inangnya. Cuaca berkabut dan lembab pada malam hari, yang diikuti oleh sinar matahari yang cerah di pagi hari dapat menstimulasi pembentukan konidia dalam jumlah besar pada daun yang terinfeksi fungi ataupun patogen lainnya, dan dapat memicu terjadinya epidemi.

\section{KESIMPULAN}

Persentase dan intensitas serangan hama boktor pada sengon rata-rata sebesar $56,66 \%$ (katagori berat), sedangkan persentase dan intensitas serangan penyakit karat tumor sebesar $100 \%$. Penilaian luas serangan hama dan penyakit ditentukan untuk mengetahui seberapa luas hama boktor dan penyakit karat tumor menyerang suatu tegakan dalam satu ekosistem. Semakin luas serangan penyakit, cenderung memiliki tingkat keparahan yang tinggi.

\section{UCAPAN TERIMA KASIH}

Ucapan terima kasih penulis sampaikan kepada Puslitbang Hutan yang telah mendanai penelitian dengan anggaran DIPA tahun 2016. Juga kepada teknisi kami di laboratorium hama penyakit kelti Perlindungan Hutan.

\section{DAFTAR PUSTAKA}

Anonim. (2014) (a). Teknik pengendalian penyakit karat puru pada pohon sengon. Diperoleh dari bp2sdmk.dephut.go.id//25.teknik.penge ndalian.penyakit.karat.puru.pada.poho. sengon. diakses tanggal 26 febuari 2018.

Anonim. (2014) (b). Penyakit karat puruuromycladim teperrianum pada sengon. Diperoleh dari https;//harjoshrian.blogspot.com/2014/1 2/penyakit-karat-puruuromycaldium.html. diakses tanggal 26 Febuari 2018.

Anonim. (2013). Pengendalian penyakit karat puru pada tanaman sengon. 
Diperoleh dari bppk candimuylo. blogspot.com/2013/04/pengendalian.pe nyakit.karat.puru.pada sengon. Diakses tanggal 26 Febuari 2018.

Anggraeni, I. (2008) (a). Penyakit karat tumor (gall rust) pada tanaman sengon (Paraserianthes falcataria) di RPH Pandantoyo, BKPH Pare, KPH Kediri. Workshop Serangan Karat Tumor pada Sengon. Balai Besar Penelitian Bioteknologi dan Pemuliaan Tanaman Hutan. Yogyakarta 19 November 2008.

Anggraeni, I. (2008). Penyakit karat puru pada sengon (Paraserianthes falcataria) dan teknik pengendaliannya. Booklet. Pusat Litbang Hutan Tanaman. Bogor.

Anggraeni, I., B. Dendang dan N. E. Lelana. (2010). Pengendalian penyakit karat tumor (Uromycladium tepperianum (Sacc.) Mc. Alpin) pada sengon (Falcataria mollucana (Miq.) Barneby \& J.W. Grimes) di Panjalu Kabupaten Ciamis Jawa Barat, Jurnal Penelitian Hutan Tanaman, 7 (5), 273-278.

Anggraeni dan Lelana. (2011).Penyakit karat tumor pada sengon. Badan Penelitian Dan Pengembangan Kehutanan. Jakarta.

Duladi. (2012). Cara cerdas mengendalikan hama dan penyakit pada sengon. Kampus IPB Taman Kencana Bogor : PT. Penerbit IPB Press.

Husaeni, E. (2010). Xystrocera festiva Thoms (Cerambycidae: Coleoptera). Biologi dan Pengendaliannya Pada Hutan Tanaman sengon. Bogor : IPB.

Husaeni., E. (2001). Hama Hutan Tanaman. Fakultas Kehutanan. IPB.

Krisnawati, H., E. Varis, M. Kallio, and M. Kanninen. (2011). Paraserianthes falcataria (L.) Nielsen: Ecology, Silviculture, Productivity. Center for International Forestry Research.
Siregar, Z.S., Yunanto, T., dan Ratnasari, J. (2009). Kayu sengon, prospek bisnis, budidaya, panen dan pascapanen. 84 pp. Jakarta. Penebar Swadaya.

Meliala, C. (2009). Pengantar Ilmu Penyakit Tumbuhan. Yogyakarta : Gadjah Mada University Press.

Nasution, Ahmad Sanusi., (2008). Mengenal Kayu Sengon. Diperoleh dari http:// Sanoesi. Wordpress.com/2008/12.

Rahayu, S. (2007). Karat Tumor Disease Of Falcataria moluccana on Tawau, Sabah, Malaysia (PhD. Thesis). Universitas Putra Malaysia, Malaysia.

Rahayu, S. (2008). Penyakit karat tumor pada sengon (Falcataria moluccana Miq). Dalam. Makalah Workshop Serangan Karat Tumor pada Sengon. Yogyakarta 19 Nopember 2008. Balai Besar Penelitian Bioteknologi dan Pemuliaan Tanaman Hutan.

Rahayu, S., Lee,S.S., Nor Aini. (2010). Gall Rust Disease On Falcataria moluccana(Miq). Barneby \& J.W. Grimes in Malaysia And Indonesia. Hand Book. UPM Press, Serdang, Selangor, Malaysia (in Press). Dalam Workshop Industri Kehutanan Berbasis Huran Rakyat.

Rahayu, S. (2014).Strategi Pengelolaan Penyakit Tanaman Hutan di Indonesia. Penyakit Karat Tumor Pada Tanaman Sengon (Falcatria moluccana). Yogyakarta : Gadjah Mada University Press.

Sinaga, M. (2006). Dasar-dasar Ilmu Penyakit Tumbuhan. Jakarta : Penebar Swadaya. 